\title{
14. MAPPING NEOGENE DEPOSITIONAL GEOMETRIES, NEW JERSEY CONTINENTAL SLOPE, LEG 150 DRILLING AREA ${ }^{1}$
}

\author{
Craig S. Fulthorpe, ${ }^{2}$ Gregory S. Mountain, ${ }^{3}$ and Kenneth G. Miller ${ }^{4}$
}

\begin{abstract}
We have interpreted and mapped multichannel (MCS) and single-channel (SCS) seismic data from the middle Atlantic margin, offshore New Jersey, encompassing Ocean Drilling Program Leg 150 drill sites on the present upper slope, to reveal threedimensional depositional geometries and slope morphologies and provide insight into slope evolution. Interpretation and mapping focused on six seismic reflections from the upper Oligocene to upper Miocene section, which constitute a subset of a large number of seismic horizons identified during Leg 150. The reflections are considered probable sequence boundaries, although the defining geometries are found beneath the shelf, not in the region of the slope where the drill sites are located.

Structure and isochron maps reveal how slope depocenters evolved as the shore-connected shelf/slope sediment prism prograded toward the study area. Post-upper Oligocene depositional fabrics are commonly oriented along strike (i.e., along slope). During parts of the middle and late Miocene, sediment accumulated in accommodation space seaward of secondary slope breaks, which formed seaward of the primary clinoform breakpoints associated with the prograding shelf/slope sediment prism. Isochrons of upper Miocene sediments illustrate the arrival of the toe of the shelf/slope sediment prism at the southwestern edge of the study area.

Pre-Pleistocene canyons are rare within the study area. A large, buried, middle Miocene (reflection m3) canyon differs markedly from modern slope canyons in its broad, planar floor. We infer that the canyon formed as a result of slope failure, though later canyon fill exhibits evidence of downslope sediment transport. Younger, middle and upper Miocene canyons mapped on reflections $\mathrm{ml}$ and $\mathrm{m} 0.5$ are narrower and $\mathrm{V}$-shaped. Both slope failure (probably coupled with headward erosion) and downslope erosion may have contributed to canyon formation at different times and on different parts of the slope. The presence of canyons together with lithological evidence of mass-flow deposits highlights the role of downslope sedimentary processes, confined and unconfined, in controlling erosion and deposition during the Miocene. Hemipelagic deposition appears to have been the dominant sedimentary process between mass-flow and canyon-cutting events.
\end{abstract}

\section{INTRODUCTION}

Primary goals of Ocean Drilling Program (ODP) Leg 150 were to: (1) date sequence-bounding unconformities to permit interbasinal sequence correlations, mainly in the Oligocene-Holocene "Icehouse" interval of known glacioeustasy, and (2) test the sequence stratigraphic model as applied to the deep-water setting of the continental slope (Miller and Mountain, 1994). Local depositional and tectonic processes and geological conditions (e.g., rates of subsidence and sediment supply, sediment source geometry, sediment compaction, isostasy, current activity, and physiography) vary within basins in three dimensions and all interact with eustasy to produce a range of sequence geometries. The stratigraphic response to those processes must, therefore, be studied in three dimensions. We have carried out seismic interpretation and mapping with the objectives of documenting the geometries of Oligocene-Miocene slope depocenters and buried canyons in the vicinity of Leg 150 drill sites, thereby placing the drilling results within a three-dimensional context.

Isochron maps have been used to reveal three-dimensional depositional geometries of the U.S. Atlantic margin by Mountain and Tucholke (1985), Poag (1985, 1992), Poag and Mountain (1987), Poag and Sevon (1989), and Poag and Ward (1993). Poag and Sevon (1989), Poag (1992), and Poag and Ward (1993), working at continental margin scale, documented the importance of tectonic uplift

Mountain, G.S., Miller, K.G., Blum, P., Poag, C.W., and Twichell, D.C. (Eds.), 1996. Proc. ODP, Sci. Results, 150: College Station, TX (Ocean Drilling Program).

${ }^{2}$ University of Texas, Institute for Geophysics, 8701 North Mopac Expressway, Austin, TX 78759-8397.U.S.A. craig@utig.ig.utexas.edu

${ }^{5}$ Lamont-Doherty Earth Observatory, Columbia University, Palisades, NY 10964. U.S.A

Department of Geological Sciences, Rutgers University, Piscataway, NJ 08855, and erosion in the hinterland in controlling the locations and migration of offshore depocenters, including the middle Miocene prograding shelf/slope sediment prism offshore New Jersey. Mountain and Tucholke (1985) focused, again at continental margin scale, on more distal slope and rise settings and emphasized the role of bottom currents in controlling erosion and deposition, beginning in the Oligocene. They noted the absence of lobate fans on the slope and rise, ascribing this to the influence of currents. Poag (1985) and Poag and Mountain (1987) examined a smaller area of the slope and upper rise, offshore New Jersey, and stressed the importance of downslope erosion and deposition on the lower slope and upper rise, based on identification of numerous Mesozoic and Cenozoic buried channels.

The present study focuses on a yet smaller scale than Poag (1985) and Poag and Mountain (1987). Seismic data acquired in support of, and during, Leg 150 provide dense coverage within the Leg 150 drilling area. Although the seismic data are not three dimensional in the processing sense (e.g., enabling three-dimensional migration and time slicing), existing data density is such that it is possible to map the three-dimensional geometries of sediment bodies beneath the present slope at scales of $\sim 50 \mathrm{~m}$ vertically and $\sim 3 \mathrm{~km}$ horizontally. Spatial variations in depositional architecture should reflect largescale drainage patterns, distance from sources of sediment supply, subsidence rates, compaction, and influence of currents. Temporal variations in sequence geometries have a secular component resulting from changes in the above controls, as well as a cyclic component caused by eustasy and related processes.

\section{DATA AND METHODS}

Seismic data comprise single-channel seismic (SCS) profiles shot by the JOIDES Resolution during Leg 150 and 60 -fold multichannel seismic (MCS) profiles acquired by the Ewing in 1990 in support of 


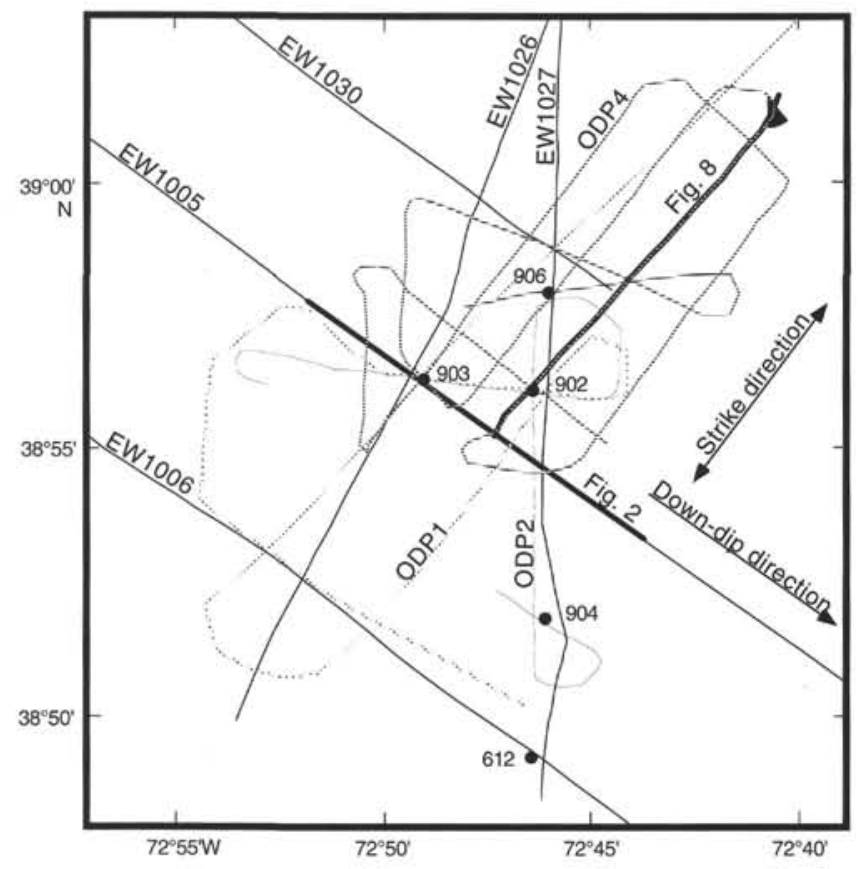

Figure 1. Map showing seismic data used in this study. Ew1005, 1006, 1026, 1027, and 1030 are multichannel seismic profiles acquired in 1990 using the Ewing. ODP1, 2, and 4 are single-channel seismic data shot during Leg 150 by the JOIDES Resolution. This seismic grid is also shown on all structure and isochron maps. Dip and strike directions are highlighted and locations of profiles in Figures 2 and 8 are shown.

New Jersey Margin drilling (Fig. 1). Traveltimes of Leg 150 data were adjusted to compensate for a $\sim 100 \mathrm{~ms}$ delay introduced during data acquisition (Mountain et al., 1994). The data form an irregular grid in the Leg 150 drilling area in which line spacings vary from $<1$ to $8 \mathrm{~km}$. The study area extends $30 \mathrm{~km}$ along strike (i.e., along slope) and $20 \mathrm{~km}$ in the dip direction (i.e., downslope).

Reflections beneath the slope tend to be parallel or to converge seaward and it is not always clear whether reflections terminate by onlap, downlap, or truncation, or simply because of loss of acoustic resolution as bed thicknesses decrease (apparent truncation). This renders ambiguous sequence stratigraphic interpretations based solely on seismic profiles from the slope. Seismic reflections beneath the shelf commonly have clinoform geometries and sequences there are more easily defined. Sequence stratigraphic interpretations of the shelf section have been carried out by Greenlee and Moore (1988) and Greenlee et al. (1988, 1992). The resulting sequence boundaries were traced from beneath the shelf to the drill sites on the slope before Leg 150 (Miller and Mountain, 1994). Because of uncertainties in correlating reflections between shelf and slope, however, an independent alphanumeric labeling system for slope reflections was defined during Leg 150. The alphanumeric slope reflections are tentatively correlated with sequence boundaries defined beneath the shelf (Table 1, Fig. 2; Mountain, Miller, Blum, et al., 1994). Further work with an expanded seismic data set is needed to define the precise relationships between alphanumeric slope reflections and sequence boundaries defined beneath the shelf.

A subgroup of six of the alphanumeric slope reflections chosen as Oligocene and Miocene sequence boundaries (o1, m3, m2, m1, m0.7, $\mathrm{m} 0.5$; Fig. 2) has been tied around the seismic grid in the vicinity of the Leg 150 drill sites. This subgroup was chosen to investigate the morphology and evolution of the slope seaward of the Neogene prograding, shore-connected shelf/slope sediment prism (Greenlee et al., 1988, 1992). For this purpose, structure and isochron maps have been
Table 1. Correlation of alphanumeric reflections defined on the slope during Leg 150 with sequence-bounding reflections defined beneath the shelf.

\begin{tabular}{|c|c|}
\hline $\begin{array}{l}\text { Slope reflection } \\
\text { (alphanumeric) }\end{array}$ & $\begin{array}{c}\text { Relection color scheme } \\
\text { and shelf reflection } \\
\text { equivalence }\end{array}$ \\
\hline pl & yellow \\
\hline p2 & blue \\
\hline p3 & green \\
\hline p4 & purple \\
\hline p5 & blue \\
\hline p6 & orange \\
\hline m0.5 & Red $^{\mathrm{a}}$ \\
\hline $\mathrm{m} 0.7$ & blue \\
\hline m1 & Tuscan" \\
\hline $\mathrm{m} 2$ & Yellow-2 ${ }^{\mathrm{a}}$ \\
\hline $\mathrm{m} 3$ & Blue $^{a}$ \\
\hline $\mathrm{m} 4$ & Pink-2u \\
\hline $\mathrm{m} 5$ & Green $^{a}$ \\
\hline m6 & pink- $3^{b}$ \\
\hline ol & green- $2^{b}$ \\
\hline el & yellow \\
\hline e2 & red \\
\hline
\end{tabular}

Note: Horizons in bold type were mapped in this study. ${ }^{\text {a }}$ Possibly equivalent to shelf sequence boundaries of this color (Greenlee et al., 1992). ${ }^{b}$ Possibly equivalent to shelf sequence boundaries of this color (G.S. Mountain et al., unpubl. data).

produced to reveal three-dimensional depositional geometries of the sequences. The reflections chosen appear to bound seismic units within which reflection geometries are fairly uniform. Therefore, mapping of additional horizons between them was not judged to be necessary, especially in view of the uncertain role of seismic interference, which can obscure a direct relationship between reflections and geological features. The large number and dense concentration of potential Oligocene-Miocene sequence boundaries, coupled with the difficulty of tracing horizons around the grid such that their sequence stratigraphic characteristics (onlap, truncation, etc.) are uniform, suggests that some may be interference composites in parts of the study area. The Pliocene-Pleistocene section is seismically complex, with evidence of numerous sequence stratigraphic surfaces. However, dissection by modern canyons (e.g., Pratson et al., 1994) prevented mapping of Pliocene-Pleistocene horizons with the available data. We have, therefore, focused on reflections from the Oligocene through Miocene section.

Seismic interpretation was carried out using GeoQuest software, which provided an output of digitized seismic horizons in units of two-way traveltime. The interpretations differ somewhat from those of Mountain, Miller, Blum, et al. (1994) and those of Lorenzo et al. (this volume). Interpretations in most cases, however, do not differ by more than a single reflection cycle, which does not significantly alter the maps produced for this study. However, the location of horizon y of Lorenzo et al. (this volume), tentatively correlated by them with $\mathrm{ol}$, is $\sim 50 \mathrm{~ms}$ shallower at Site 906 than o1 as interpreted here.

GMT (Wessel and Smith, 1991) was used for constructing structure and isochron maps of the interpreted horizons. Maps were plotted within a region bounded by latitudes $38^{\circ} 48^{\prime} \mathrm{N}$ and $39^{\circ} 03^{\prime} \mathrm{N}$ and longitudes $72^{\circ} 39^{\prime} \mathrm{W}$ and $72^{\circ} 57^{\prime} \mathrm{W}$.

Within that region, the contoured areas of structure and isochron maps form irregular shapes dictated by data coverage and reflection geometries. The northwestern (landward) boundaries of all contoured areas (except the $\mathrm{m} 0.7$ and seafloor structure maps and $\mathrm{m} 0.7-\mathrm{m} 0.5$ isochron map) are identical and were selected both because seismic data coverage northwest of the drill sites is relatively sparse and because of the difficulty of unambiguously following reflections westward beneath the present-day shelf edge. The northwestern boundaries of the $\mathrm{m} 0.7$ structure map and $\mathrm{m} 0.7-\mathrm{m} 0.5$ isochron map are defined by the truncation of reflection $\mathrm{m} 0.7$ by reflection $\mathrm{m} 0.5$. Contouring of the seafloor structure map was allowed to fill in the entire northwestern part of the map area because the seafloor in that area 

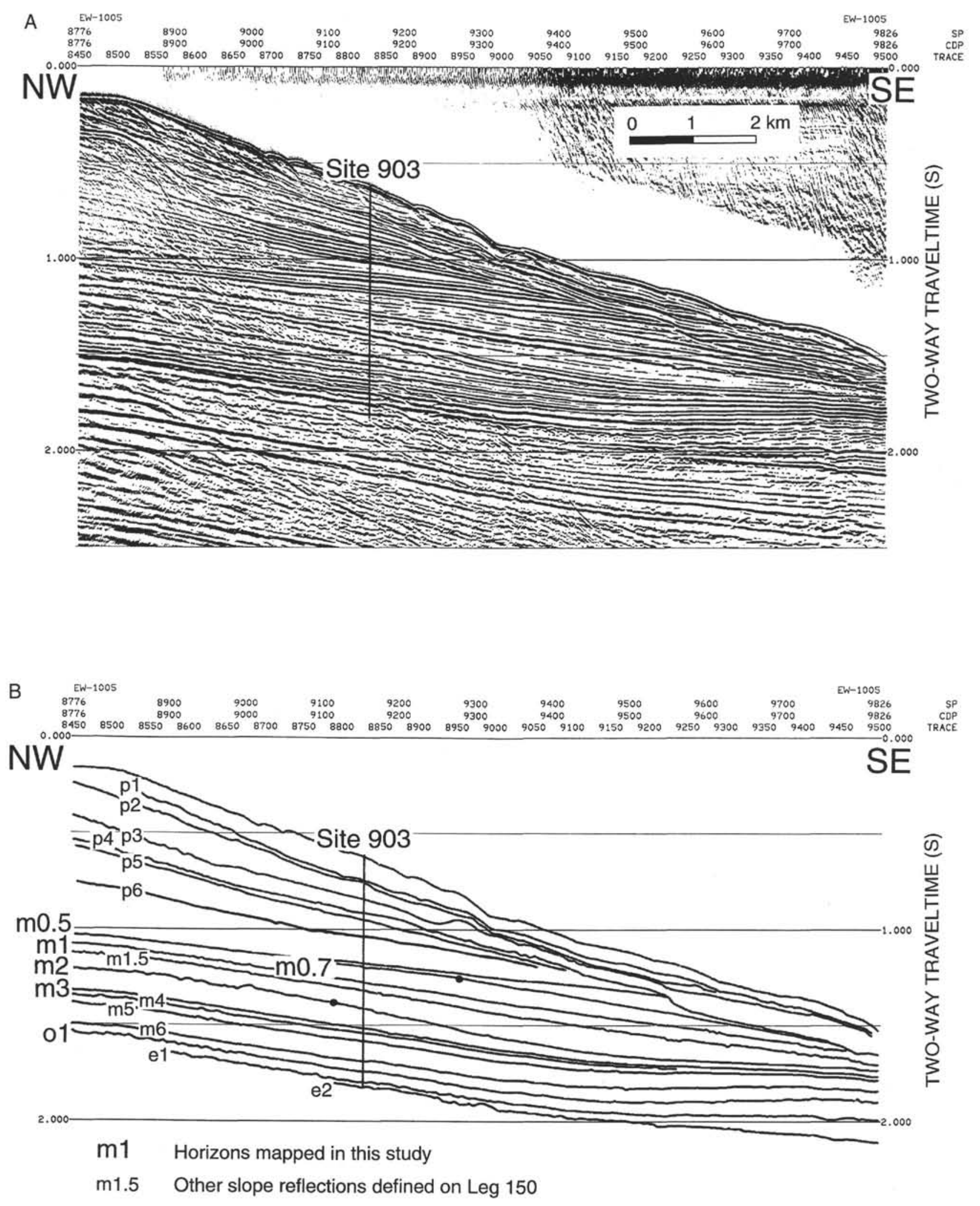

Figure 2. A. Uninterpreted MCS profile Ew1005. See Figure 1 for location. B. Interpretation of Ew 1005 showing alphanumeric labeling system for slope reflections. These reflections are tentatively correlated with sequence boundaries defined beneath the shelf (Mountain, Miller, Blum, et al., 1994). The horizons mapped in this study are o1, $\mathrm{m} 3, \mathrm{~m} 2, \mathrm{ml}, \mathrm{m} 0.7$, and $\mathrm{m} 0.5$. Dots mark distal, secondary slope breakpoints on $\mathrm{m} 2$ and $\mathrm{m} 0.7$. Note thinning of underlying units and thickening of overlying units seaward of the secondary breakpoints. 


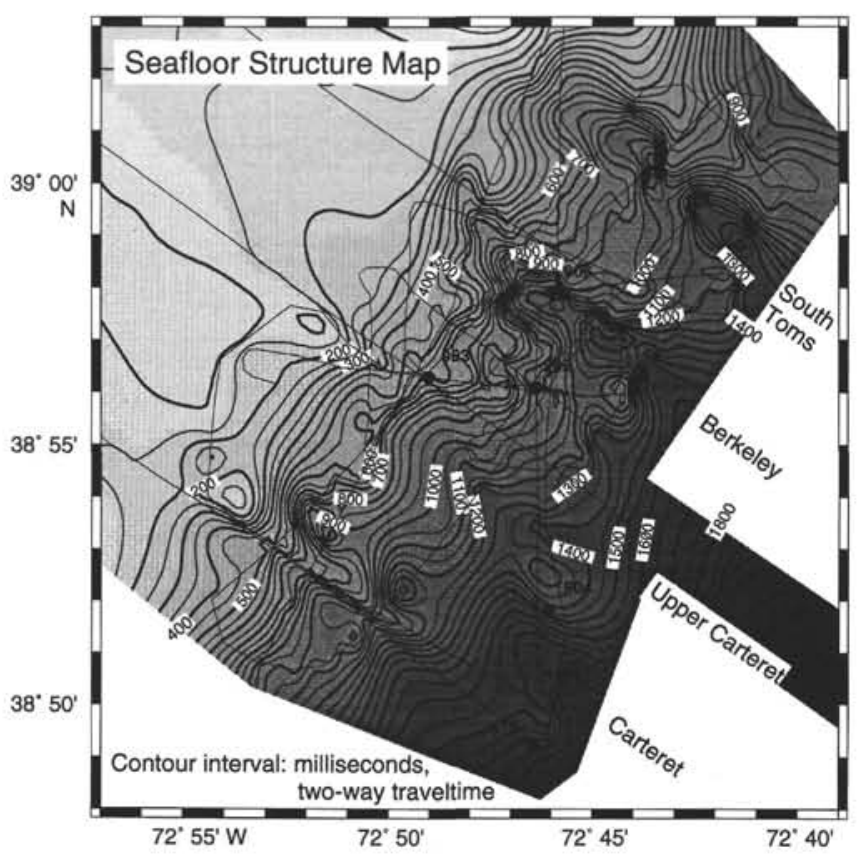

Figure 3. Structure map of seafloor horizon derived from the seismic grid shown in Figure 1 and showing modern canyons incising the slope. Compare the resolution of bathymetric features with the SeaBeam bathymetry shown in Figure 4.

lies on the shelf, which is known to be fairly horizontal. Southeastern (seaward) boundaries of contoured areas differ for each horizon. There, maps are truncated where horizons do not exist or cannot be mapped because of: (1) absence of seismic data, (2) truncation, by either another horizon or the seafloor, or (3) inability to track a reflection because of canyon dissection. Because the goal of isochron mapping was to evaluate depositional processes within units and depositional and erosional processes influencing unit boundary geometries, isochron maps (with the exception of the $\mathrm{m} 1-\mathrm{m} 0.7$ isochron map, discussed below) were contoured only where the structure maps of the upper and lower bounding surfaces overlapped areally. Differing areal extent of bounding surfaces is primarily the result of Pleistocene erosion (e.g., by p4 on Fig. 2) at the seaward edges of mapped surfaces, which yield peripheral unit geometries unrelated to syn- and immediately postdepositional processes. Such regions are not included in the isochron maps.

Comparison of the seafloor structure map (Fig. 3) with the more detailed SeaBeam bathymetry (Fig. 4) provides an indication of how faithfully the seismic data and GMT contouring routine recover horizon morphologies. Some detail is lost in the seismic mapping process. The main canyons (South Toms, Berkeley, Upper Carteret, and Carteret) were delineated, but others (e.g., Middle and Lower Berkeley) and other unnamed features resolved by SeaBeam are not reconstructed by seismic mapping.

\section{RESULTS}

\section{Seismic Unit o1-m3}

Reflection ol is associated with a strong velocity and density contrast and an unconformity between upper Eocene chalk and upper Oligocene siliciclastic sediments. This horizon correlates with the top of the Baltimore Canyon Alloformation of Poag and Ward (1993). Strontium isotopic measurements yielded a hiatus from $\sim 37$ to $32 \mathrm{Ma}$ at Site 903, where the hiatus was shortest (Miller et al., this volume).

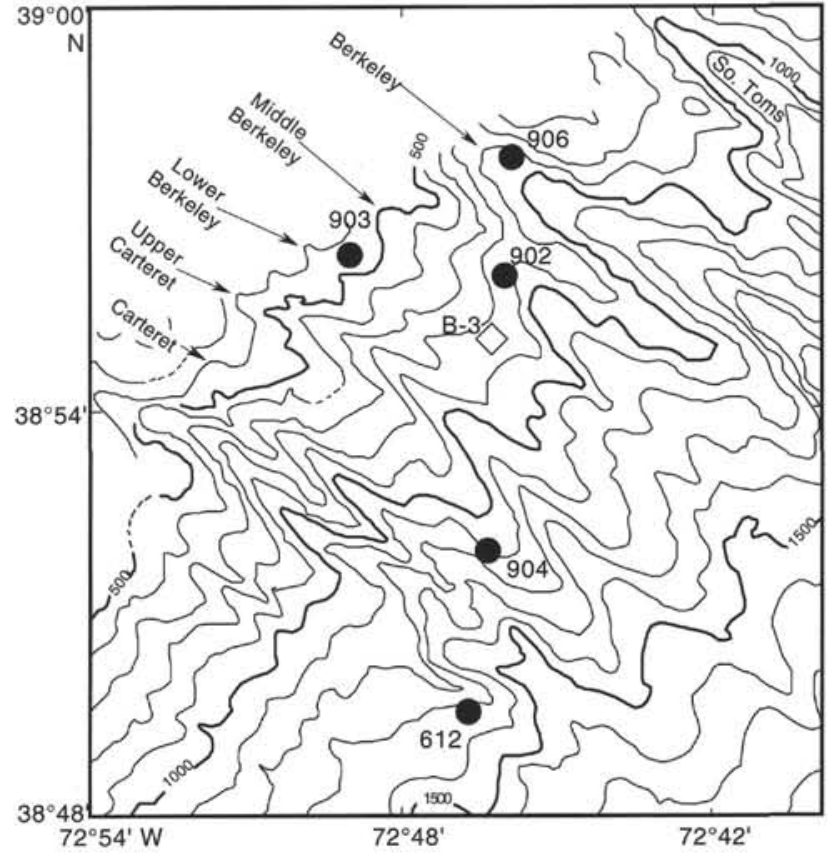

Figure 4. SeaBeam bathymetric map of the middle continental slope in the Leg 150 drilling area. Canyons are shown in greater detail than in Figure 3. Also shown are locations of Leg 150 slope drill sites (902-904 and 906), DSDP Site 612, and the COST B3 well. Contour interval in meters below sea level.

The marked change from carbonate to terrigenous deposition, the "siliciclastic switch," probably occurred during the early Oligocene $(\sim 34.5 \mathrm{Ma})$ and correlates with a $\delta^{18} \mathrm{O}$ increase (Miller et al., this volume). The study area is far seaward $(\sim 90 \mathrm{~km}$, based on unpublished oil industry seismic data) of the o1 shelf/slope clinoform breakpoint and o1 displays gentle seaward (southeasterly) dips (gradient $~ 1: 35$ ) in the western half of the mapped area (Figs. 2, 5). Dips are reduced in the southeastern part of the study area and even reverse in direction to become landward (negative gradient $~ 1: 40$; Fig. 2). Reflection o1 forms the base level for the subsequent development of the slope.

No canyons incise ol within the study area. Apparent downslope drainage features appear on Figure 5, but these are related to velocity pull-down beneath modern canyons. Velocity pull-down, together with vertical misalignment of correlative reflections on adjacent or crossing seismic lines (because of navigational imprecision or constant offsets in traveltime measurement) can lead to artifacts resembling geomorphological features on maps in units of traveltime. The presence of such artifacts is often revealed by their repeated occurrence on structure maps of several horizons. Only map features that are unambiguously present on seismic profiles and are unique to particular horizons are here assigned geological significance.

Reflection $\mathrm{m} 3$, representing a middle middle Miocene horizon (13.5 Ma; Mountain, Miller, Blum, et al., 1994; Miller et al., this volume), dips gently seaward in the western part of the study area (gradient $\sim 1: 40$ ). Its dip decreases toward the southeast to become slightly landward (Figs. 2,6). Reflection $\mathrm{m} 3$ is interpreted to represent the surface into which a large buried canyon drilled at Site 906 was cut. It is the youngest surface that is always cut by the canyon on canyoncrossing profiles within the study area (Mountain et al., this volume). The canyon forms an embayment on the $\mathrm{m} 3$ structure map (Fig. 6) at Site 906 and can also be seen on the o1-m3 isochron map (Fig. 7) as a thinning of this unit caused by erosion of pre-m 3 sediments during canyon formation. In the region covered by seismic profile ODP4 (Fig. 1), where the canyon is best displayed on seismic profiles, the 


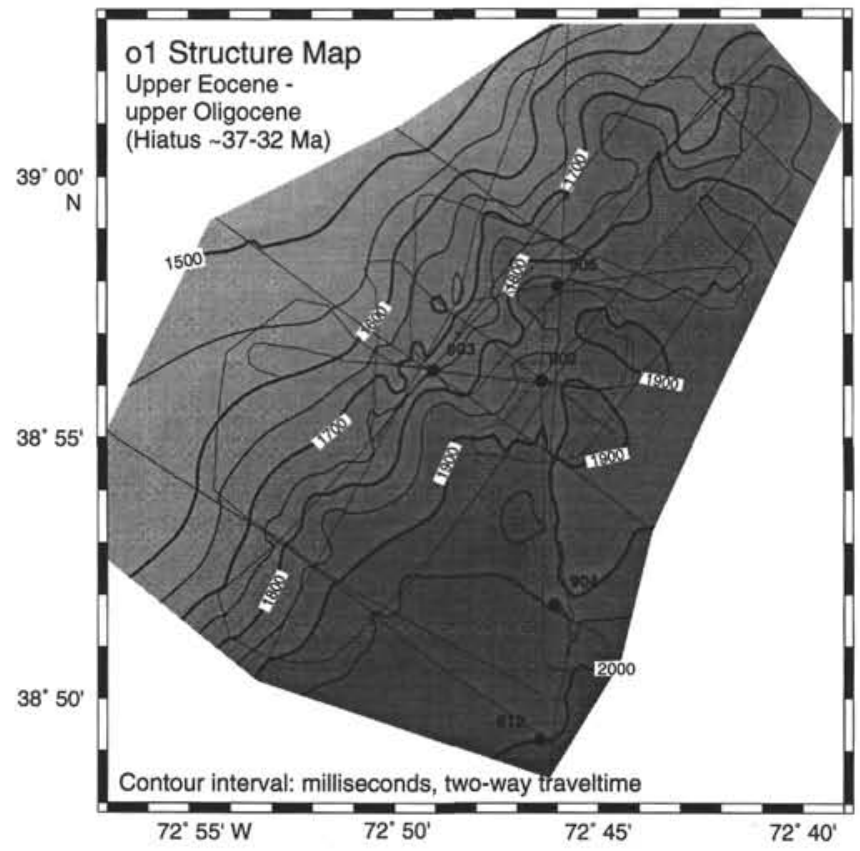

Figure 5. Structure map of ol horizon. Reflection ol marks an unconformity between upper Eocene chalks and upper Oligocene siliciclastic sediments.

width of the canyon varies from approximately 3 to $4 \mathrm{~km}$ over a length of about $7 \mathrm{~km}$ in the axial direction (Fig. 6). The maximum erosional relief of the canyon walls in this region (measured between the floor of the canyon and the interpreted location of $\mathrm{m} 3$ on its rim) is $\sim 0.17 \mathrm{~s}$ two-way traveltime $(\sim 160 \mathrm{~m})$ and the relief decreases seaward. The canyon floor is broad and planar and dips seaward, but also has a transverse (southwestward) component of dip (Fig. 8). Seismic coverage landward of ODP4 is sparse and the upslope extent of the canyon is therefore uncertain. The most landward strike profile, Ew1026 (Fig. 1) shows the canyon to be a considerably narrowed feature, $<1 \mathrm{~km}$ wide; in this study, the canyon was also interpreted to be less deeply incised on Ew1026 than on more seaward profiles (Fig. 6). Mountain et al. (this volume) inferred a more deeply incised, but still narrow, upslope thalweg on Ew1026.

A possible second canyon cut at $\mathrm{m} 3$ time lies at the extreme northern end of the study area (Canyon 2 of Mountain et al., this volume). Although not constrained by multiple seismic line crossings, it is revealed as an embayment on Figure 6 and as erosional thinning on Figure 7 (see also Fig. 8). Reflection $\mathrm{m} 3$ also truncates underlying reflections elsewhere on the slope, where the section is not dissected by canyons.

The o1-m 3 unit is characterized by parallel reflection geometries, but isochrons (Fig. 7) show that the o1-m3 unit has a subtle thickness maximum, oriented along strike. This maximum is roughly centered in the study area and is cut by the Site 906 canyon. At Site 903, sediments of the o1-m3 interval (1049-796 m below seafloor [mbsf]; Mountain, Miller, Blum, et al., 1994) comprise a basal $3 \mathrm{~m}$ of wellcemented, coarse glauconitic sand at ol overlain by slightly to moderately bioturbated silty claystone with minor glauconite (lithologic Unit VI) and highly diatomaceous, slightly to moderately bioturbated, glauconitic silty clays with sporadic meter-scale, upward-fining, glauconitic fine sand beds (lower lithologic Unit V; Mountain, Miller, Blum, et al., 1994). At $\sim 60 \mathrm{~m}$ below m3, woody plant material becomes more common uphole, indicating increasing terrigenous influx. The upward-fining fine sand beds were interpreted as turbidites by Mountain, Miller, Blum, et al. (1994). Foraminifer and nannofos-

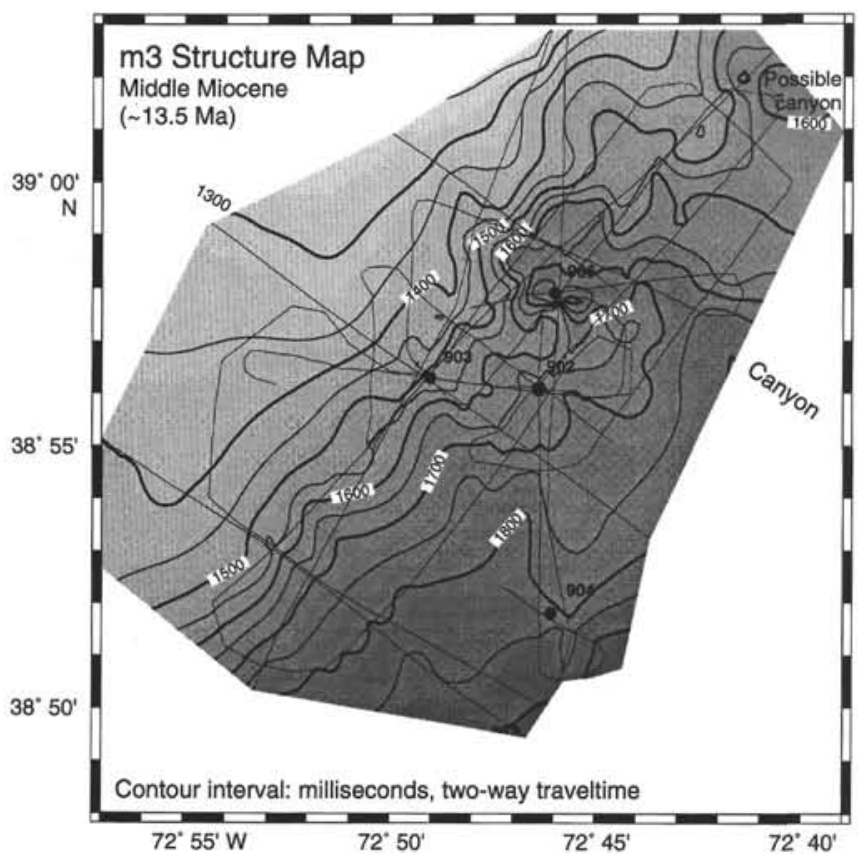

Figure 6. Structure map of middle middle Miocene $\mathrm{m} 3$ horizon showing a buried canyon indenting the slope in the vicinity of Site 906 .

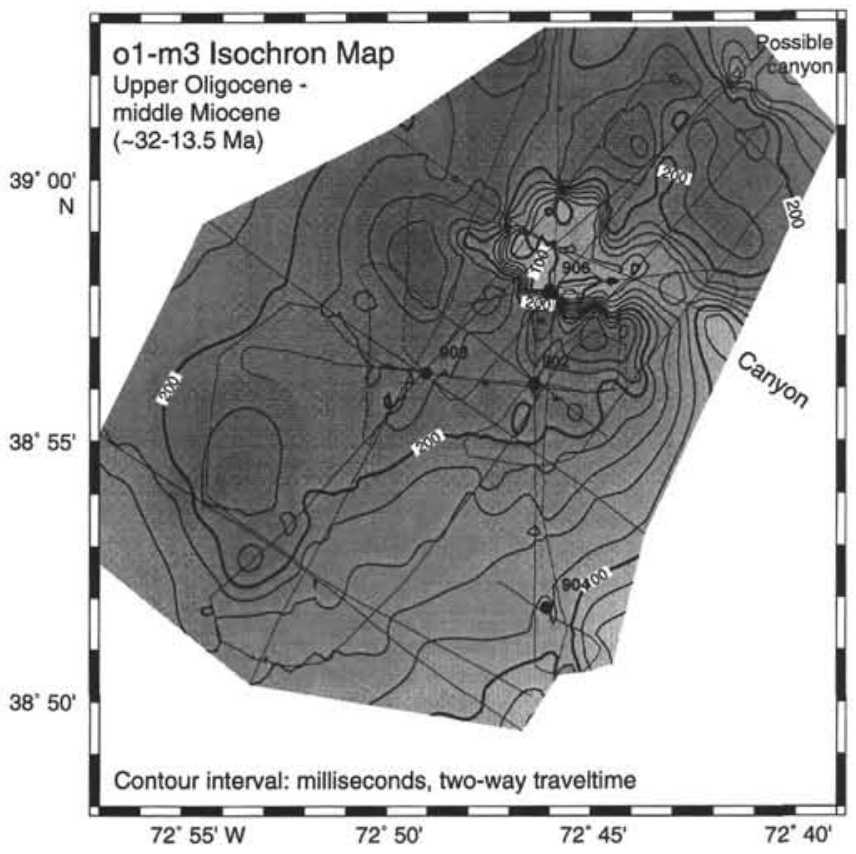

Figure 7. Isochron map of upper Oligocene to middle middle Miocene seismic unit o1-m 3 . Note the thinning of this unit beneath the $\mathrm{m} 3$ canyon.

sil abundances decrease upward in the o1-m 3 interval and diatoms become the most common microfossils.

\section{Seismic Unit m3-m2}

Horizon m2 (Fig. 9; middle middle Miocene, $~ 12.5$ Ma; Mountain, Miller, Blum, et al., 1994; Miller et al., this volume) dips gently 

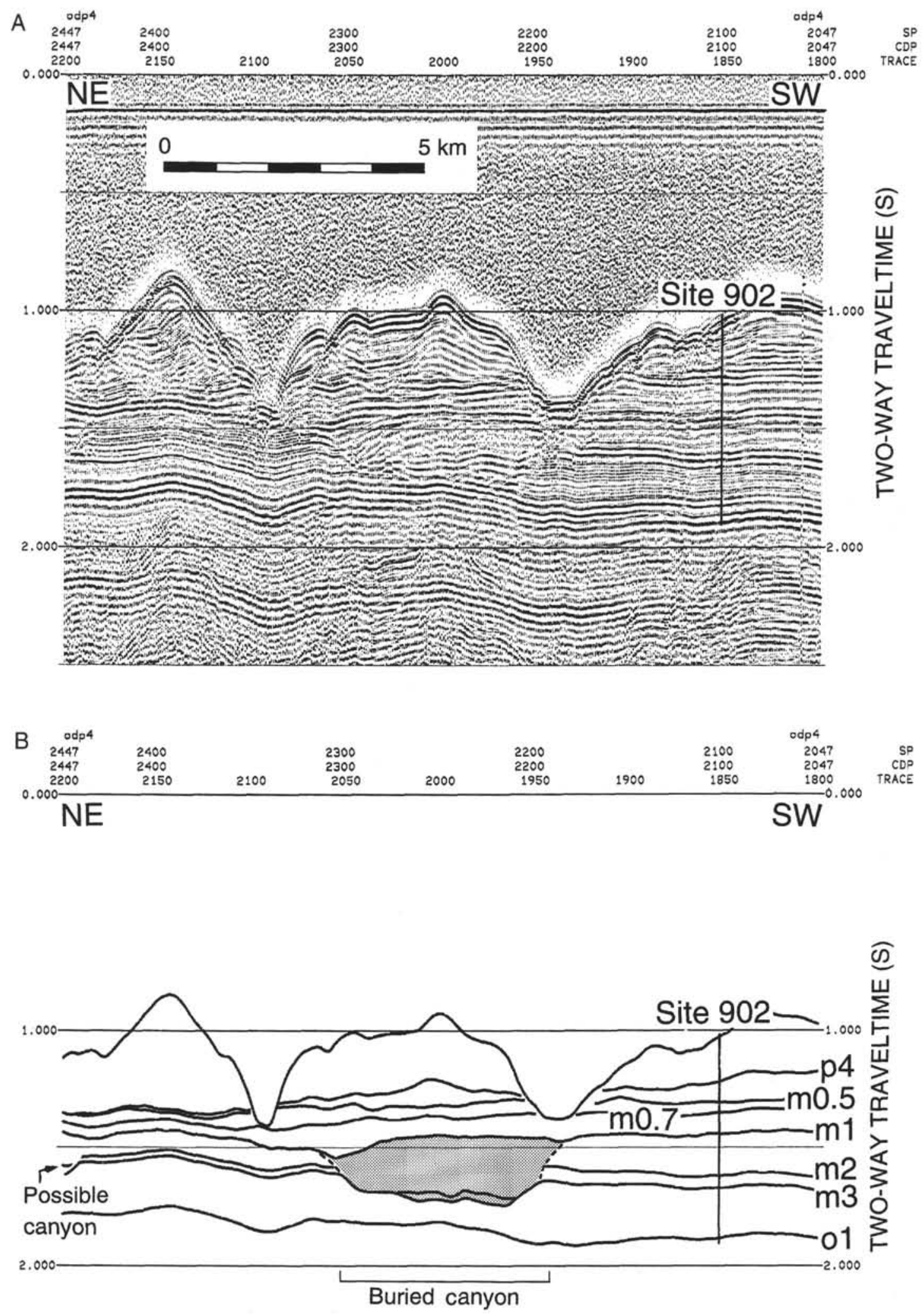

Figure 8. A. Uninterpreted SCS profile ODP4 crossing the m3 canyon. See Figure 1 for location. B. Interpretation showing only horizons mapped in this study together with $\mathrm{p} 4$. The canyon (shaded) is interpreted to have been incised at $\mathrm{m} 3$ time (early middle Miocene). Note the northward-dipping canyon fill and remnant $\mathrm{V}$-shaped canyon that existed until at least $\mathrm{m} 1$ time (upper middle Miocene). The planar floor of the canyon dips southward. Evidence of a second possible $\mathrm{m} 3$ canyon can be seen at the northeastern end of the profile. 


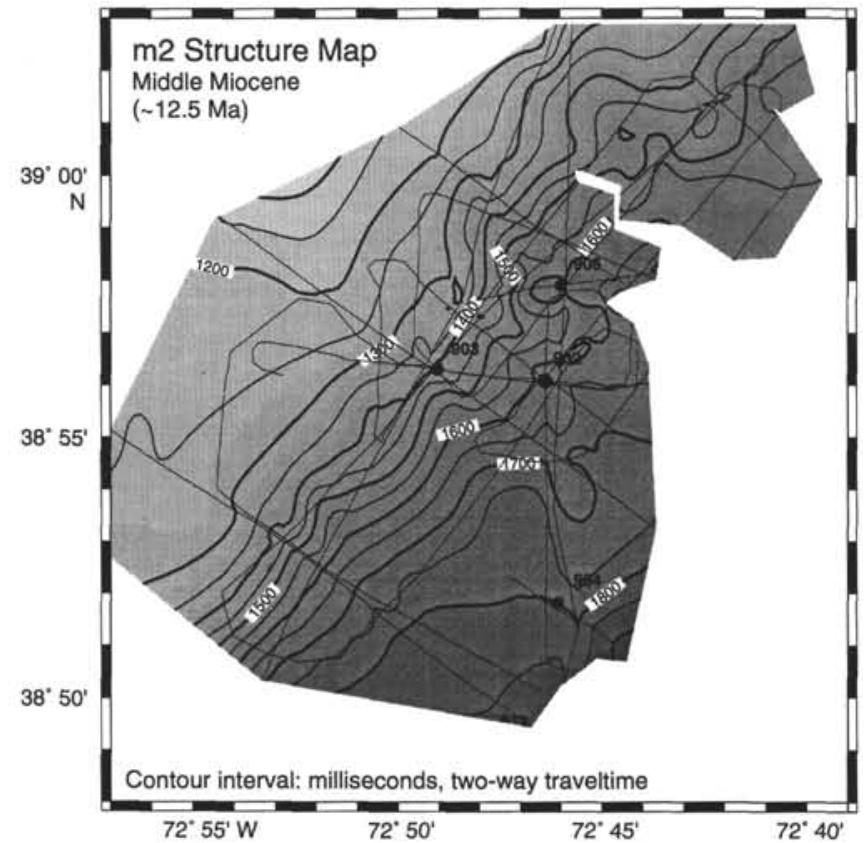

Figure 9. Structure map of middle middle Miocene $\mathrm{m} 2$ horizon. Unmapped indentations near Site 906 result from termination of $\mathrm{m} 2$ against the walls of the $\mathrm{m} 3$ canyon.

seaward in the western part of the study area (gradient $\sim 1: 35$ ), but displays steepened dips (gradient $\sim 1: 25$ ) beneath the modern upper slope (Fig. 2). As with o1 and $\mathrm{m} 3$, dips are reduced in the southeastern part of the study area (Figs. 2,9). Seismic profiles show that $m 2$ displays a subtle, distal slope breakpoint (Fig. 2), though the primary clinoform breakpoint, associated with the prograding shore-connected sediment prism, is $\sim 20 \mathrm{~km}$ landward of the study area (Greenlee et al., 1992). As a result, the $m 3-m 2$ unit generally thins seaward across the entire study area (Fig. 10). The unit is characterized by parallel reflection geometries. Reflection $\mathrm{m} 2$ may truncate underlying reflections seaward of its distal clinoform breakpoint, but evidence for such truncation is uncommon and not well defined in this slope setting.

Reflection $\mathrm{m} 2$ is interpreted as arising from strata forming part of the $\mathrm{m} 3$ canyon fill. On landward canyon-crossing profiles, $\mathrm{m} 2$ is continuous across the canyon and onto the adjacent slope. On more seaward crossing profiles, however, $\mathrm{m} 2$ terminates against the canyon walls, with terminations at the northern wall occurring at more landward locations than terminations at the southern wall (as marked by unmapped indentations near Site 906 on Fig. 9). This is a result of the northerly dips displayed by the canyon fill on many canyon-crossing profiles (Fig. 8). Away from the $\mathrm{m} 3$ canyon, the slope at $\mathrm{m} 2$ time was fairly featureless (Fig. 9), even though horizon $\mathrm{m} 2$ is associated with delivery of sand to Sites 902, 903, and 904 (Mountain, Miller, Blum, et al., 1994) and can also be correlated with a glacioeustatic lowstand (Mi4 of Miller et al., 1991).

Correlation of the m3-m2 interval to Sites 902,903 , and 904 shows a distinctive facies succession. Sands or sandy muds occur at the base, nodular concretions are concentrated in the middle, and laminated or massive muds occur at the top. Sediments at Site 903 (796-700 mbsf; Mountain, Miller, Blum, et al., 1994) are highly diatomaceous, slightly to moderately bioturbated, glauconitic silty clays with sporadic meter-scale, upward-fining, glauconitic, fine sand beds (upper lithologic Unit V; Mountain, Miller, Blum, et al., 1994). A 4-m-thick interval of redeposited strata, interpreted as slumps or debris flow deposits by Mountain, Miller, Blum, et al. (1994), occurs at the base of lithologic Subunit IVB at 733-729 mbsf

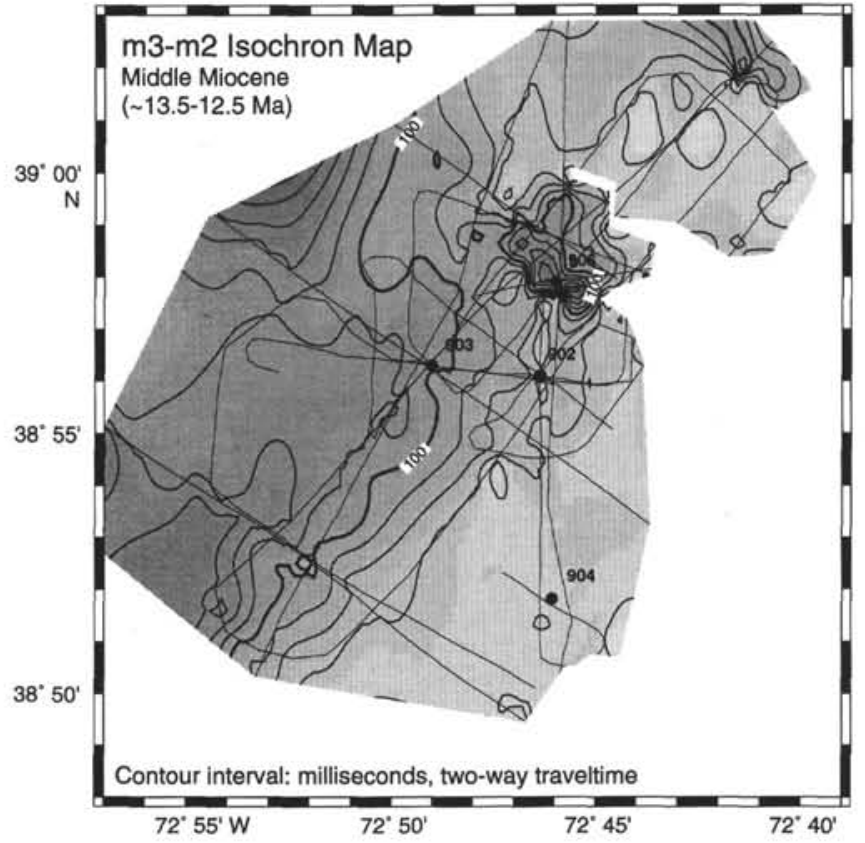

Figure 10. Isochron map of middle middle Miocene seismic unit m3-m2.

within the $\mathrm{m} 3-\mathrm{m} 2$ interval at Site 903 . Reflection $\mathrm{m} 2$ correlates with the base of a sand layer at $\sim 700 \mathrm{mbsf}$ at Hole $903 \mathrm{C}$ and with an interval of no recovery, possibly sandy, at the top of Unit V at Site 902 (Mountain, Miller, Blum, et al., 1994). Facies successions within the Site 906 canyon are particularly striking. Silty clay and interspersed beds of mud-clast conglomerate with a 10 -cm-thick slump bed at the base (lithologic Subunit VC) are overlain by an interval of fine quartz sand and silty clay and contorted silty clay and sand (lithologic Subunit VB). This is overlain in turn by laminated silty clay (lithologic Subunit VA; Mountain, Miller, Blum, et al., 1994). The birth and demise of the Site 906 buried canyon are discussed in detail by Mountain et al. (this volume).

\section{Seismic Unit $m 2-m 1$}

The precise age of upper middle Miocene horizon $\mathrm{ml}$ is not well constrained, but lies between 10.6 and $11.3 \mathrm{Ma}$ (Miller et al., this volume). Reflection $\mathrm{m} 1$ dips gently seaward (gradient $\sim 1: 50$; Figs. 2, 11). Therefore, because of the underlying $\mathrm{m} 2$ breakpoint, a pronounced thickening of the $\mathrm{m} 2-\mathrm{m} 1$ unit occurs in the southeastern part of the study area, but it thins toward the $m 3$ canyon (Fig. 12). A thinner depocenter exists north of the $\mathrm{m} 3$ canyon. Reflections in the $\mathrm{m} 2-$ $\mathrm{ml}$ unit are parallel, dipping southeastward. Internal reflections both onlap landward and downlap seaward a strong positive reflection a full reflection cycle above $\mathrm{m} 2$ (Fig. 2). It is not clear why the onlapped surface is not identical with $\mathrm{m} 2$. It is possible that sequence boundary $\mathrm{m} 2$ should be placed a cycle higher. Selection of $\mathrm{m} 2$ was based on ties to clinoforms beneath the shelf (Mountain, Miller, Blum, et al., 1994). Interpretation of the overlying onlapped surface as $\mathrm{m} 2$ would not, however, greatly affect the results of mapping.

Reflection $\mathrm{m} 1$ is continuous across the $\mathrm{m} 3$ canyon drilled at Site 906 on most canyon-crossing profiles, but terminates against the northern canyon wall on the most seaward crossing profiles (unmapped indentation northeast of Site 906 on Fig. 11). A V-shaped canyon existed within the study area at the northern edge of the buried $\mathrm{m} 3$ canyon until at least $\mathrm{m} 1$ time. It is only clearly displayed at $\mathrm{ml}$ on the more seaward strike profiles (Fig. 8). The $\mathrm{m} 3$ canyon was filled from south to north resulting in this remnant canyon remaining 


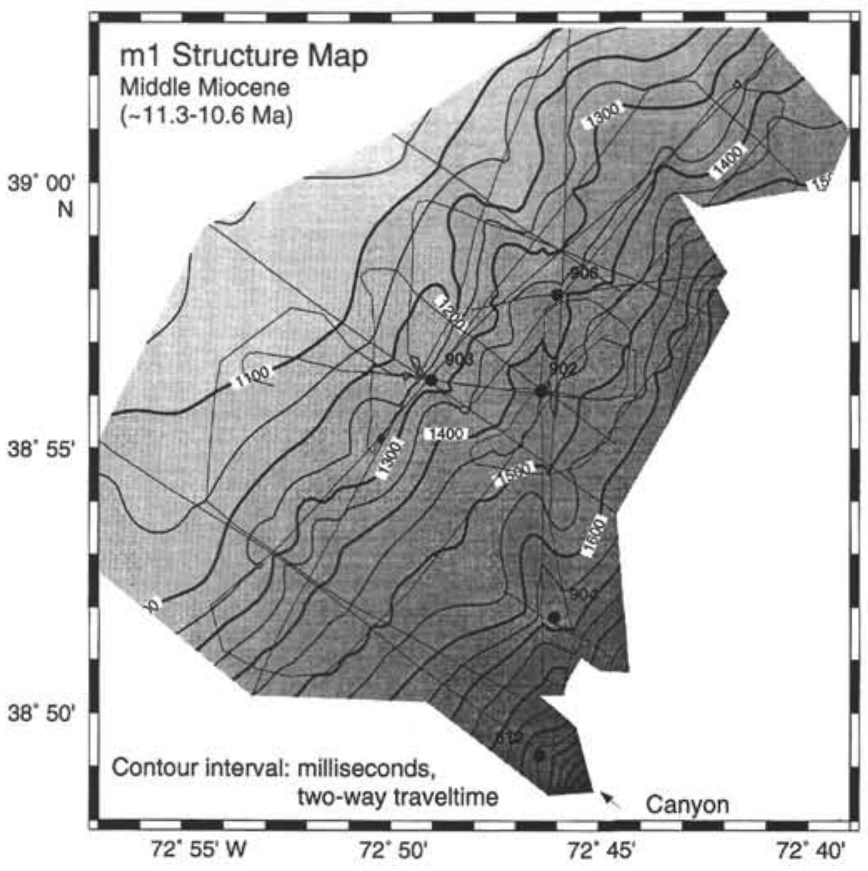

Figure 11. Structure map of upper middle Miocene $\mathrm{m} 1$ horizon. Note the buried canyon at DSDP Site 612.

open at its northern edge. A buried, V-shaped, erosional canyon at $\mathrm{m} 1$ was drilled at Deep Sea Drilling Project (DSDP) Site 612, $\sim 5 \mathrm{~km}$ south of Site 904 (Fig. 11). At Site 903, sediments in the m2-m1 unit (604.5-700 mbsf) comprise a basal unit of sand, correlative with $\mathrm{m} 2$, overlain by silty clay (lithologic Subunit IVB; Mountain, Miller, Blum, et al., 1994). Also at Site 903, an interval of slumps occurs at the base of lithologic Subunit IVA between 602.5 and 624.5 mbsf. Reflection $\mathrm{ml}$ was correlated with the base of a slump at $604.5 \mathrm{mbsf}$ by Mountain, Miller, Blum, et al. (1994).

\section{Seismic Unit m1-m0.7}

Westward truncation by $\mathrm{m} 0.5$ and seaward truncation by $\mathrm{p} 4$ have the result that lower upper Miocene horizon m0.7 ( 8.0-8.5 Ma; Mountain, Miller, Blum, et al., 1994) is mappable only within a restricted area (Fig. 13). Reflection m0.7 is significant, however, because it displays a subtle breakpoint within the study area close to its termination against $\mathrm{m} 0.5$ on Figure 2. Gradients landward of the breakpoint are very low $(<1: 100)$, increasing to $\sim 1: 30$ seaward of the breakpoint. This breakpoint is analogous to that displayed by $\mathrm{m} 2$. Reflections in the m1-m0.7 unit are mostly parallel, with minor clinoforms near the seaward edge of the unit. Reflection $\mathrm{m} 0.7$ is onlapped and truncation occurs at a positive reflection a half cycle below m0.7.

The isochron map (Fig. 14) shows thicknesses between $\mathrm{m} 1$ and $\mathrm{m} 0.7$ in the seaward half of the mapped area where the latter is present as a separate reflection (i.e., within the contoured area of Fig. 13). The landward half of Figure 14 shows thicknesses between $\mathrm{ml}$ and $\mathrm{m} 0.5$, with which $\mathrm{m} 0.7$ is merged in this region. The gentle breakpoint exhibited by $\mathrm{m} 0.7$ coupled with the shallow seaward dip of $\mathrm{m} 1$ causes the $\mathrm{ml}-\mathrm{m} 0.7$ unit to develop a subtle thickness maximum, with its long axis oriented along strike, along the seaward half of the mapped area (Figs. 2,14). Dissection by more recent slope canyons also affects the mappable area of m0.7, resulting in unmapped indentations on Figures 13 and 14. The thickening at the southwestern edge of the mapped area represents the arrival of the toe of the $\mathrm{m} 0.5$ shelf/slope clinoform in the study area (Fig. 14).

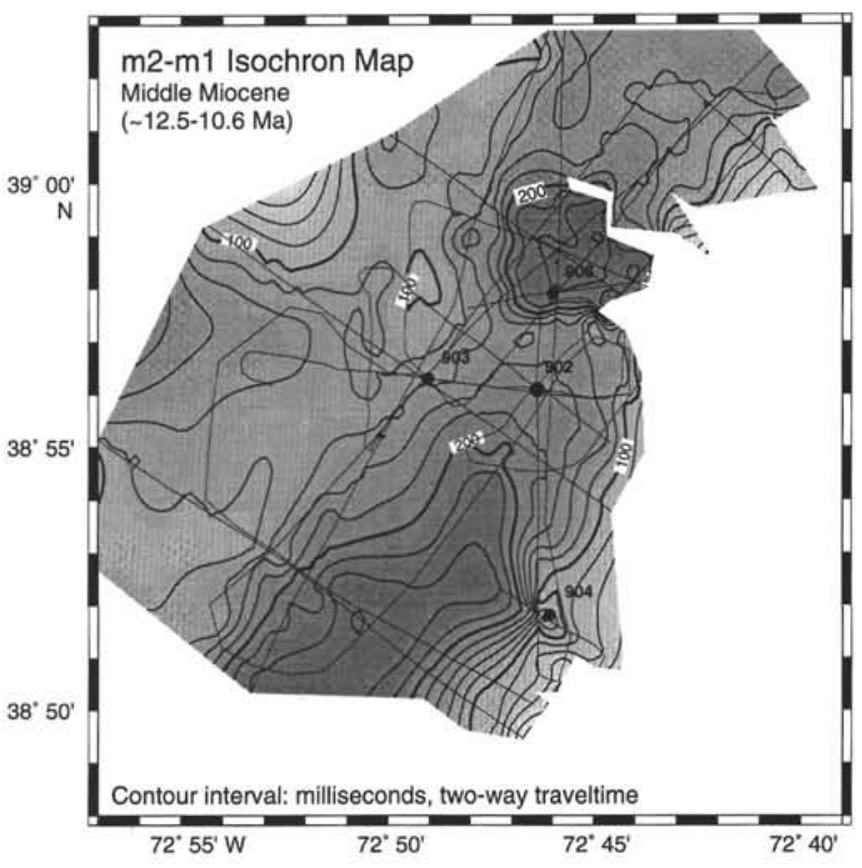

Figure 12. Isochron map of middle Miocene seismic unit m2-m1. Absolute ages quoted represent upper bounds on the time interval represented by the mapped unit.

Sediments within the $\mathrm{m} 1-\mathrm{m} 0.7$ interval comprise predominantly moderately bioturbated silty clay and clayey silt. At Site 903 , fine to coarse glauconitic sand and slumps (one of which is coincident with $\mathrm{ml}$ at $604.5 \mathrm{mbsf}$ ) occur at the base of the interval, whereas loose sand, containing abundant granule-sized quartz grains, occurs at this stratigraphic level at Site 902 (289 mbsf; Mountain, Miller, Blum, et al., 1994). Mountain, Miller, Blum, et al. (1994) did not identify m0.7 at Site 903 because it is truncated by $\mathrm{m} 0.5$ in the vicinity of this site. Horizon m0.7 was, however, present at Site 902 at $~ 208$ mbsf. Abundant plant and wood fragments were observed in thin laminations and disseminated throughout cores at Site 902 (lower lithologic Subunit IVA; Mountain, Miller, Blum, et al., 1994). The highest concentration of wood and plant debris lies in the upper $10 \mathrm{~m}$ of the interval (209-219 mbsf), just below m0.7.

\section{Seismic Unit m0.7-m0.5}

Upper Miocene horizon m0.5 ( 8.0 Ma; Mountain, Miller, Blum, et al., 1994) dips seaward more gently (gradient $\sim 1: 100$ ) in the central part of the study area than do reflections o1 to $\mathrm{m} 1$ and does not display a breakpoint within the mapped area (Figs. 2, 15). A prominent, $\mathrm{V}$-shaped, erosional canyon incises m 0.5 near the southern end of the mapped area and indents contours on Figure 15. Mountain et al. (this volume) interpreted a second canyon incising m0.5 immediately above the $\mathrm{m} 3$ canyon on line Ew1026, but this feature cannot be traced to adjacent lines and was not mapped in this study. Because m0.7 dips more steeply than $\mathrm{m} 0.5$, the $\mathrm{m} 0.7-\mathrm{m} 0.5$ unit thickens seaward until the entire unit is truncated by $\mathrm{p} 4$ (Figs. 2,16). Reflections between $\mathrm{m} 0.7$ and $\mathrm{m} 0.5$ are parallel and onlap $\mathrm{m} 0.7$. The $\mathrm{m} 0.5$ structure map shows dissection by modern slope canyons across the study area (unmapped indentations on Fig. 15).

Sediment in the m0.7-m0.5 interval at Site 902 (208-152 mbsf) is predominantly moderately bioturbated silty clay and clayey silt (upper lithologic Subunit IVA; Mountain, Miller, Blum, et al., 1994). A concentration of siderite nodules occurs near the top of the interval 


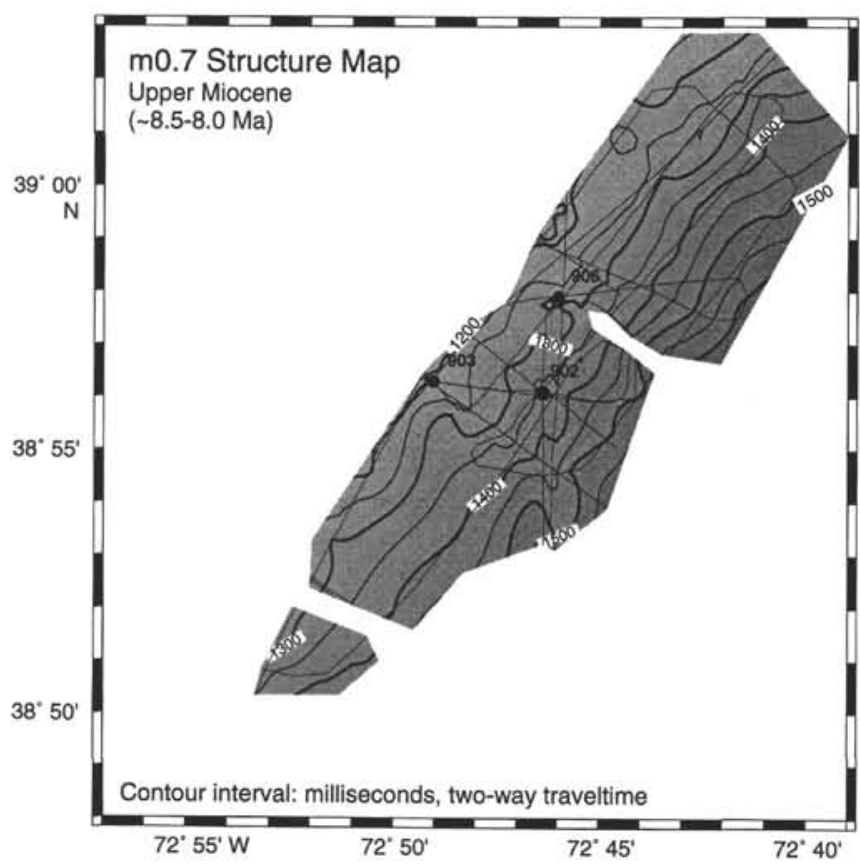

Figure 13. Structure map of lower upper Miocene m0.7 horizon. Reflection $\mathrm{m} 0.7$ is truncated by $\mathrm{m} 0.5$ in the landward part of the study area, limiting the mappable area of m0.7.

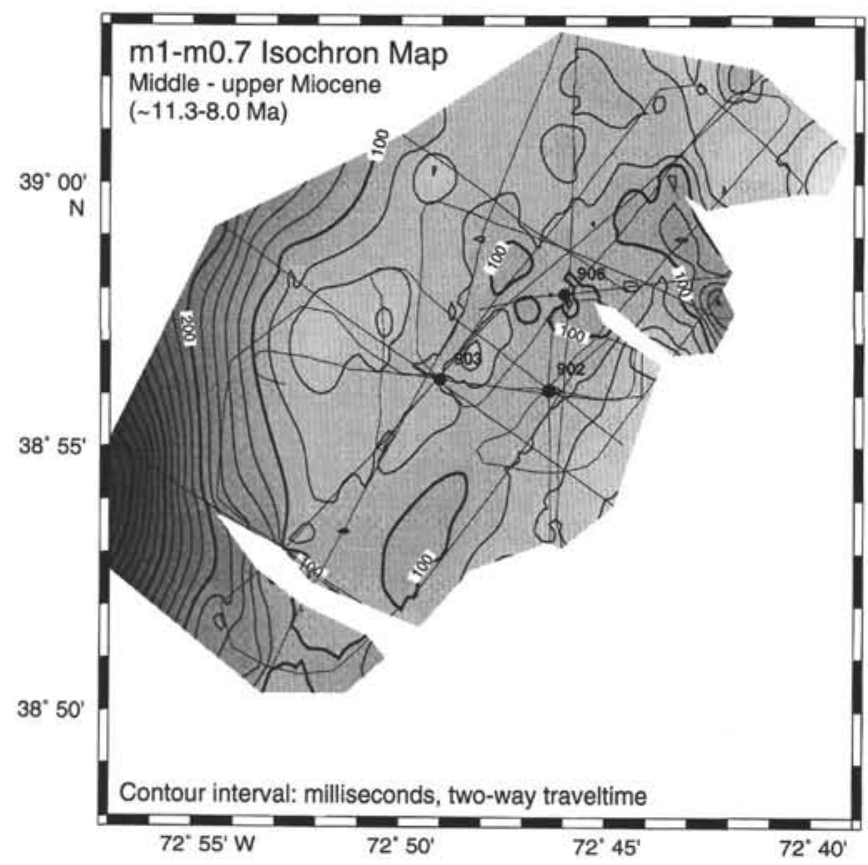

Figure 14. Isochron map of upper middle to lower upper Miocene seismic unit $\mathrm{m} 1-\mathrm{m} 0.7$. Isochrons between $\mathrm{ml}$ and $\mathrm{m} 0.5$ are displayed landward of the truncation of $\mathrm{m} 0.7$ by $\mathrm{m} 0.5$. Absolute ages quoted represent upper bounds on the time interval represented by the mapped unit.

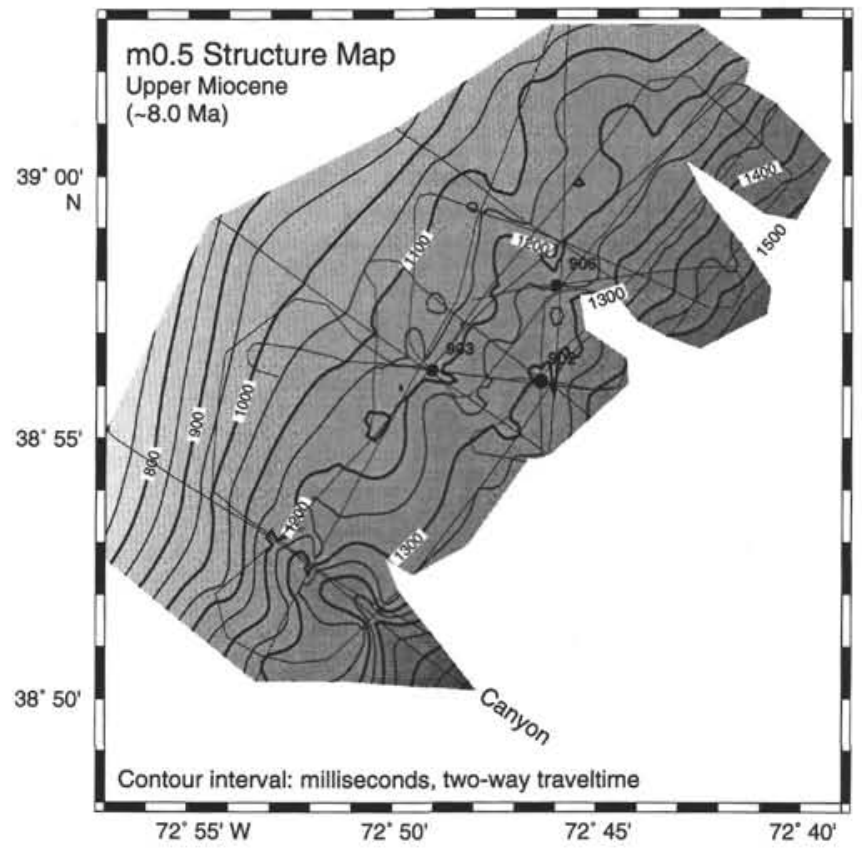

Figure 15. Structure map of upper Miocene m0.5 horizon. Note canyon indenting the slope up to the 1200 -ms contour at the southern end of study area.

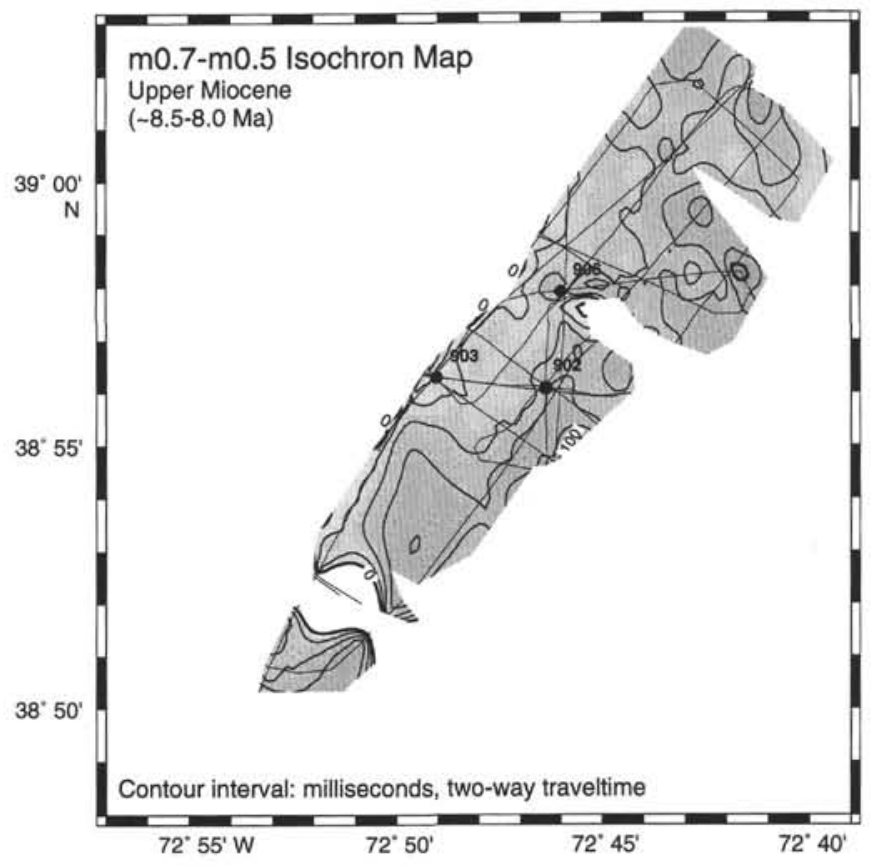

Figure 16. Isochron map of upper Miocene seismic unit m0.7-m0.5. Absolute ages quoted represent upper bounds on the time interval represented by the mapped unit. 


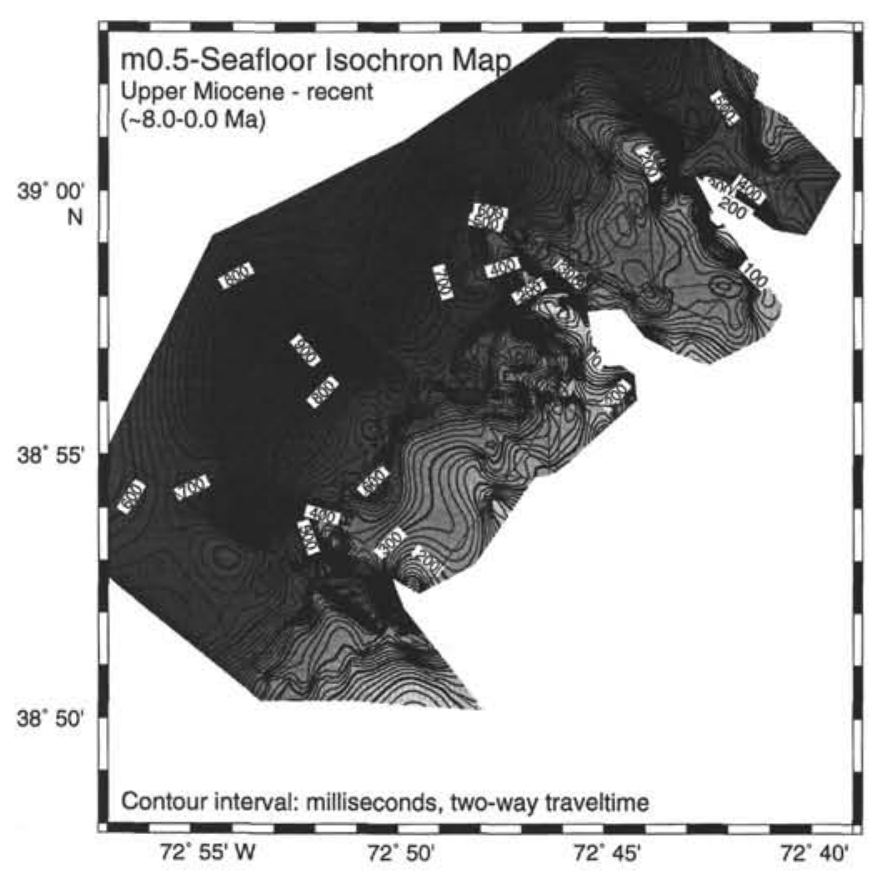

Figure 17. Isochron map of upper Miocene to recent seismic unit m0.5-seafloor.

at 152.5-156 mbsf, approximately coincident with $\mathrm{m} 0.5$, which lies at the boundary between lithologic Units III and IV. At Site 903, however, $\mathrm{m} 0.5$ is correlated with a glauconite sand at $500 \mathrm{mbsf}$ within, but near the base of, lithologic Unit III (Mountain, Miller, Blum, et al., 1994).

\section{Seismic Unit m0.5-Seafloor}

The seafloor structure map (Fig. 3) illustrates the morphology of the modern slope as derived from the seafloor reflections on the available seismic profiles. The development of the m0.5-seafloor interval is best described with reference to intervening horizon $\mathrm{p} 4$ (Figs. 2, 8). Reflection 44 is produced by a middle Pleistocene horizon that lies close to an unconformity between upper Miocene and upper Pleistocene sediments at Sites 902 and 904 (Mountain, Miller, Blum, et al., 1994). The development of the modern slope within the study area was far advanced by $\mathrm{p} 4$ time ( $440 \mathrm{ka})$ and $\mathrm{p} 4$ dips steeply seaward (Fig. 2). It was not possible to map reflection $\mathrm{p} 4$ with the available seismic data because of dissection of $\mathrm{p} 4$ by modern canyons. Reflection $\mathrm{p} 4$, however, marks a distinct change in seismic facies within the m0.5-seafloor unit. The m0.5-p4 interval is characterized by reflections that converge seaward and the unit thickens landward, reflecting the progradation of the toe of the shelf/slope sediment prism across the study area (Fig. 2). The p4-seafloor interval, in contrast, contains variable seismic facies including parallel, mounded, and chaotic reflections (Fig. 2). Because of the clinoform geometries of both $\mathrm{m} 0.5$ and the seafloor, the $\mathrm{m} 0.5$-seafloor unit displays a thickness maximum within the study area beneath the modern outer shelf and upper slope (Fig. 17).

Sediments between m0.5 and p4 (500-252 mbsf) at Site 903 comprise intercalated glauconitic very fine sand and sparsely glauconitic, moderately bioturbated silty clay with woody plant fragments (lithologic Unit III). These are overlain by intervals of bioturbated nannofossil silty clays and poorly sorted, fine to very coarse sand, some of which is normally graded (lithologic Unit II; Mountain, Miller, Blum, et al., 1994). Woody material was particularly abundant in the

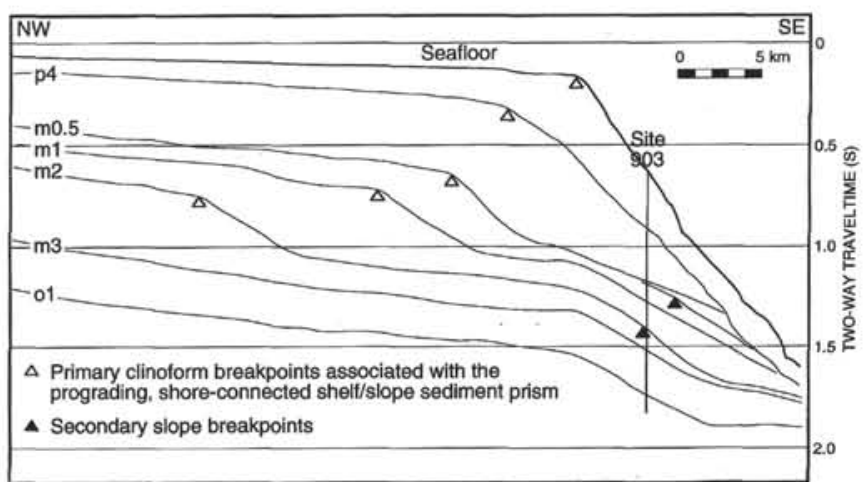

Figure 18. Interpretation of MCS profile Ew1005 showing progradation of shore-connected shelf/slope sediment prisms (hintershelves of Poag and Ward, 1993) toward the Leg 150 drilling area and locations of primary and secondary breakpoints. Note thinning of underlying units and thickening of overlying units seaward of the secondary breakpoints.

5-m interval immediately above $\mathrm{m} 0.5$. Lithologic Unit II is absent at Site 902 , but Unit III also contains abundant glauconitic sands at Site 902. Sediments between p4 ( $252 \mathrm{mbsf}$ at Site 903$)$ and the seafloor comprise heavily bioturbated silty clay with thin very fine sand turbidites and a thick succession of slumps at the base (lithologic Unit I; Mountain, Miller, Blum, et al., 1994). The basal slumps are correlative with p4, particularly at Site 902.

\section{DISCUSSION \\ Depositional Geometries}

Between the late Oligocene and late Miocene, the prograding, shore-connected shelf/slope sediment prism (hintershelf of Poag and Ward, 1993) migrated toward the study area from positions tens of kilometers landward of the drill sites (Fig. 18; Poag, 1987; Poag and Ward, 1993; Greenlee et al., 1992). This sediment wedge featured clinoform breakpoints at its seaward edge (hintershelf edge of Poag and Ward, 1993) during much of the period between late Oligocene and recent, but exhibited more ramplike morphology during part of the early to middle Miocene ( 21 to $\sim 14 \mathrm{Ma}$; Steckler et al., 1993). In the terminology of Poag and Ward (1993), this ramp lay on the foreshelf, seaward of underlying hintershelf edges.

Structure and isochron maps derived from seismic profiles provide a three-dimensional picture of slope evolution within the study area. Paleowater depth estimates based on benthic foraminiferal occurrences in Leg 150 boreholes are incomplete (Mountain, Miller, Blum, et al., 1994), but consistently indicate that water depths in the study area were at least upper bathyal $(200-600 \mathrm{~m})$ between the late Oligocene and late Miocene.

Throughout this period of progradation, slope sediment within the mapped units was not uniformly distributed in either the strike or dip directions. Local depocenters have been a continuing feature of slope development. In the oldest and most distal seismic unit mapped, o1$\mathrm{m} 3$ (Fig. 7), a thickness maximum centered near Site 903 is the result of a gradual reduction in the seaward dip of ol toward the southeastern part of the study area. The dip direction of ol reverses in this region to become landward, an effect visible even on seismic data displayed in traveltime (Figs. 2, 5). Seismic depth sections would exaggerate this dip reversal, which appears to be a result of seaward thickening of Eocene units below ol (Fig. 2), but may also be the result of differential compaction of Eocene and older sediments by the prograding shelf-slope sediment prism to produce a "shelf-edge anticline" (Reynolds et al., 1991). 
Sediment distribution patterns in overlying units are related to differences in the morphologies of their upper and lower bounding surfaces. For instance, seismic unit m3-m2 (Fig. 10) thins markedly seaward because a subtle slope breakpoint was produced on $\mathrm{m} 2$ within the study area (Figs. 2, 18). Evidence for erosional truncation at this breakpoint is ambiguous in this slope setting where dips are gentle, but erosion would be consistent with $\mathrm{m} 2$ being a sequence boundary. As was the case with o1, dips of both $\mathrm{m} 3$ and $\mathrm{m} 2$ flatten and become slightly landward in the southeastern part of the study area (Figs. 2, $6,9)$.

Unit m2-ml (Fig. 12) contains a well-defined depocenter (>200 ms thick) in the southern part of the study area. This thickened deposit formed in the available accommodation space seaward of the $\mathrm{m} 2$ distal slope breakpoint. The long axis of the deposit is oriented along strike and the unit thins toward the $\mathrm{m} 3$ canyon, though a thinner depocenter extends north of the canyon. The architecture of this slope sequence was controlled in part by the morphology of the underlying sequence boundary $(\mathrm{m} 2)$.

The pattern established by units $m 3-\mathrm{m} 2$ and $\mathrm{m} 2-\mathrm{m} 1$ is repeated in the next two mapped units. Unit $\mathrm{m} 1-\mathrm{m} 0.7$ (Fig. 14) is analogous to $\mathrm{m} 3-\mathrm{m} 2$ because development of a breakpoint on $\mathrm{m} 0.7$ (Figs. 2, 18) caused seaward thinning at the eastern edge of the mapped area. The overlying unit, $\mathrm{m} 0.7-\mathrm{m} 0.5$ (Figs. 2,16 ) is analogous to $\mathrm{m} 2-\mathrm{ml}$ because it too was deposited in accommodation space seaward of a breakpoint on its basal sequence boundary $(\mathrm{m} 0.7)$. Much of the $\mathrm{m} 0.7-\mathrm{m} 0.5$ unit has been truncated by $\mathrm{p} 4$.

Variations in slope morphology involving sequence boundaries with breakpoints (e.g., $\mathrm{m} 2$ and $\mathrm{m} 0.7$ on Figs. 2 and 18), separated by intervals of sequences with boundaries lacking breakpoints (e.g., $\mathrm{m} 1$ and $\mathrm{m} 1.5$ on Fig. 2) are superficially similar to those seen beneath the shelf by Steckler et al. (1993). They attributed the changes in shelf sequence architecture to the periodic development of oversteepened slopes seaward of depositional shelf breaks. Sediment bypassed such slopes to build up a downslope ramp until sufficient seaward accommodation had been filled to permit progradation of depositional shelf breaks to resume. Steckler et al. (1993), therefore, emphasized the role of preexisting margin geometry, rather than eustasy, in controlling sequence architecture, as opposed to sequence timing. There is no evidence for slope oversteepening within the study area (maximum gradients are only $\sim 1: 25$ ), but other erosive processes may have controlled sequence boundary geometry in this setting.

Subsequent to 0.5 , the arrival of the toe of the shelf/slope sediment prism in the study area caused sequence architecture to become dominated by shelf/slope clinoforms. Seismic stratigraphy above $\mathrm{m} 0.5$ is complex and truncation by modern canyons limits the potential for effective interpretation and mapping with existing data. A fuller understanding of this interval will require additional seismic data, collection of which is planned.

\section{Buried Canyons}

Documenting the history of slope canyon development is crucial to understanding processes of sediment supply to depocenters on the continental slope and rise. Pre-Pleistocene buried canyons were observed within the study area associated with reflections $\mathrm{m} 3, \mathrm{ml}$, and $\mathrm{m} 0.5$. The importance of seismic mapping to the study of buried canyons is that it allows not simply identification of buried canyons, but also delineation of their morphologies, extent in the dip direction, and spacing along strike.

Based on modern slope morphology, Twichell and Roberts (1982) and Farre et al. (1983) suggested that canyons were initiated by slope failures at the base of slope and extended by upslope erosion, possibly coupled with spring sapping (Robb, 1984). A similar conclusion was reached by Mountain (1987) in a study of buried Eocene channels in this same region. More recently, Pratson et al. (1994) integrated studies of modern slope morphology with seismic profiles show- ing buried canyons, mostly Pleistocene, and revealed inconsistencies in the upslope erosion model. Pratson et al. (1994) proposed a downslope erosion model of canyon formation in which canyons were initiated by sediment-flow erosion on the upper continental slope and were extended downslope by successive erosive events onto the midto lower slope where, because of reduced sediment cover, remnant troughs overlie buried canyons. Erosive flows tended to be captured within these troughs and to reexcavate the buried canyons (Pratson et al., 1994).

In contrast to modern canyons and more recent buried canyons, which tend to be V shaped (e.g., Pratson et al., 1994), the m 3 canyon has a broad, planar floor on seismic profiles over much of the study area (Fig. 8). Paleowater depth estimates based on benthic foraminiferal occurrences (Mountain, Miller, Blum, et al., 1994) indicate that water depths in the study area were at least upper bathyal (200-600 $\mathrm{m}$ ) immediately preceding the canyon-cutting event and upper bathyal during its subsequent filling. The canyon, therefore, lay at typical slope depths. However, the clinoform breakpoint associated with $\mathrm{m} 3$ within the prograding, shore-connected shelf/slope sediment prism lies $40 \mathrm{~km}$ landward of the drill sites. Modern slope canyons extend onto the upper slope and some intersect the shelf edge (Twichell and Roberts, 1982). The $\mathrm{m} 3$ canyon may also have extended far up its paleoslope. Available seismic profiles do not constrain the landward extent of the head of the canyon, but Figure 6 suggests that any landward extension was significantly narrower than the large feature mapped within the area of most dense seismic coverage. Much of the canyon appears, therefore, to have formed in an unusually distal slope setting.

Horizons $\mathrm{m} 2$ and $\mathrm{m} 1$ can be identified within the $\mathrm{m} 3$ canyon fill. On seaward strike profiles, both terminate against the canyon walls, predominantly the northern wall because of the northward dip of the canyon fill. A remnant, V-shaped canyon existed along at least the seaward part of the northern edge of the $\mathrm{m} 3$ canyon until $\mathrm{m} 1$ time (late middle Miocene; Fig. 8). This suggests that the canyon evolved into a conduit for downslope sediment movement analogous to those of the modern slope. The $\mathrm{m} 2-\mathrm{ml}$ depocenter in the southern part of the study area (Fig. 12) may comprise sediment that flowed down the canyon and was swept southward by bottom currents.

The planar floor of the $\mathrm{m} 3$ canyon at Site 906 and its geometry on Figure 6 are characteristic of amphitheater-shaped slide scars (Farre et al., 1983; Robb, 1984). Morphological evidence, therefore, suggests that the $\mathrm{m} 3$ canyon originated by slope failure. This conclusion was also reached by Mountain et al. (this volume), who interpreted the basal canyon fill as deriving from the slope itself and found no evidence that the canyon was cut by turbidity currents originating on the shelf. Firm evidence for headward erosion is currently lacking, but seismic evidence that the canyon evolved into a V-shaped feature supports the inference by Mountain, et al. (this volume) that headward erosion did occur and eventually tapped sediment sources on the shelf. In contrast to the mapped $\mathrm{m} 3$ canyon, the younger $\mathrm{m} 1$ and $\mathrm{m} 0.5$ buried canyons are V shaped, similar to Pleistocene and recent canyons inferred by Pratson et al. (1994) to have been formed by downslope erosion. Structure maps suggest that neither extended far landward up the paleoslope (Figs. 11,15), but seismic coverage in the southern part of the study area is limited and the existence of unmapped upslope extensions to the $\mathrm{m} 1$ and $\mathrm{m} 0.5$ canyons is likely. These observations suggest that canyon formation by both upslope erosion (Farre et al., 1983) and downslope erosion (Pratson et al., 1994) could have occurred, perhaps at different times and in different regions of the slope. Additional seismic data landward of the study area are required to document the upslope character of the buried canyons and test this hypothesis.

Downslope canyons do not appear to have been common features of the study area until the Pleistocene. Modern canyons are closely spaced and several canyon systems occur within the study area (Figs. $3,4)$. Several buried canyons also exist within the unmapped Pleis- 
tocene interval, particularly in the northern part of the study area. The two $\mathrm{m} 3$ canyons and the narrower $\mathrm{m} 1$ and $\mathrm{m} 0.5$ canyons (with a possible second $\mathrm{m} 0.5$ canyon interpreted by Mountain et al., this volume) were the only canyons noted incising the six mapped horizons within the study area, though, as noted above, the Site $906 \mathrm{~m} 3$ canyon continued to exist as a remnant feature and a probable conduit for downslope sediment transport until at least $\mathrm{ml}$ time. This is in general agreement with Poag and Mountain (1987), who found few Cenozoic age channels throughout most of the present study area. Structure maps indicate subtle, dip-oriented channels on several horizons, but these are artifacts of seismic mapping.

Reflections $\mathrm{m} 3$ and $\mathrm{m} 1$ were correlated with $\delta^{18} \mathrm{O}$ increases by Miller et al. (this volume). Canyon erosion at $\mathrm{m} 1$ has also been tentatively correlated with erosional events on the Irish margin, the northwest Florida continental slope, and the Somali margin and also presumed to represent a glacioeustatic fall (Miller et al., 1987). Reflection $\mathrm{m} 0.5$ can be correlated with the $8.2 \mathrm{Ma}$ sequence boundary of Haq et al. (1987) (Mountain, Miller, Blum, et al., 1994). The three canyon-cutting events mapped in the study area, therefore, were probably all related to glacioeustatic events. Miller et al. (this volume) also correlated reflections ol and $\mathrm{m} 2$ with $\delta^{18} \mathrm{O}$ increases, but those horizons lack canyons within the study area (other than the remnant of the $\mathrm{m} 3$ canyon that existed at $\mathrm{m} 2$ time). The possible presence of canyons on those and other horizons outside the study area cannot be discounted (see Poag, 1992; Poag and Ward, 1993).

\section{Slope Depositional Processes}

Slumps, graded turbidite sands, and the presence of woody plant material and glauconite derived from shallow-water environments in cores from Sites 902-904 and 906 attest to the importance of downslope sediment transport from the late Oligocene to recent, a pattern previously documented for the middle Miocene to recent by results of DSDP Legs 93 and 95 (van Hinte, Wise, et al., 1987; Poag, Watts, et al., 1987). Further evidence derives from the existence of the buried canyons discussed above. However, along-strike oriented sediment deposits and the relative sparseness of pre-Pleistocene canyons revealed by seismic mapping point to a significant role for additional depositional processes.

Bottom current activity provides one mechanism for creating along-strike depositional and erosional geometries, e.g., the m2-m1 depocenter (Fig. 12) and distal slope breakpoints on horizons $\mathrm{m} 2$ and m0.7 (Fig. 2). Current activity has been documented on the continental rise, where it has been of primary importance in controlling Oligocene to recent deposition at the scale of the entire U.S. Atlantic margin (Mountain and Tucholke, 1985; Locker and Laine, 1992; Poag, 1992). Olsson and Wise (1987) postulated current erosion on the slope and even shelf, the latter during highstands of sea level, but their episode of submarine erosion ended in the earliest Eocene. Evidence for Oligocene to recent current activity has not been documented at upper slope locations corresponding to the study area. An alternative mechanism for generating slope depocenters oriented along strike is sediment supply from laterally shifting river sources during lowstands. Pratson et al. (1994) suggested this as a mechanism by which a small number of rivers could provide sediment to multiple submarine canyons and as a cause of along-strike thickness changes in sedimentary units.

Poag and Mountain (1987) stressed downslope processes as the primary mechanisms of deposition and erosion on the slope during the Cenozoic, though little siliciclastic sediment reached the continental rise until the middle Miocene (Poag, 1992). Uplift in the central Appalachians and cooling paleoclimate caused a 10-fold increase in siliciclastic sediment supply during the middle Miocene (Poag and Sevon, 1989; Poag, 1992). This is supported by the existence of the $\mathrm{m} 3$ canyons, which now represent the earliest canyon-cutting event documented this far landward on the New Jersey slope (e.g., Mountain, 1987), as well as the $\mathrm{ml}$ and $\mathrm{m} 0.5$ canyons.
Thick silty clay and clayey silt deposits intervene between identifiable mass flow events in Leg 150 cores. These were interpreted as hemipelagic deposits by Mountain, Miller, Blum, et al. (1994). Periodic downslope sediment transport and erosion have interrupted hemipelagic deposition. Sedimentation within the study area during the late Oligocene to late Miocene, therefore, was characterized by a combination of downslope mass transport and hemipelagic settling in an environment of widely separated canyons. The widely dispersed canyons and occurrence of downslope sediment transport on areas of the slope not incised by canyons, e.g., the slump and sand deposits associated with $\mathrm{m} 2$ and $\mathrm{m} 1$, imply that unconfined downslope transport was also common.

\section{CONCLUSIONS}

Mapping of selected stratal horizons imaged as seismic reflections and spanning the interval from upper Oligocene to upper Miocene on the New Jersey slope reveals that depocenters are commonly elongated along strike. At least some depocenters are responses to accommodation space that existed because of the morphologies of underlying seismic unit boundaries. This is particularly evident for units associated with reflections $\mathrm{m} 2$ and $\mathrm{m} 0.7$, which display subtle secondary slope breakpoints within the study area. Thickened sediment accumulations formed in the available accommodation space seaward of these breakpoints. The breakpoints formed in distal slope settings far seaward of the associated primary clinoform breakpoints within the prograding, shore-connected shelf/slope sediment prism. Onlap and possible truncation associated with $\mathrm{m} 2$ and $\mathrm{m} 0.7$ are consistent with the existence of sequence boundaries at or near these horizons and suggest that the distal breakpoints were formed by erosional processes, though the evidence remains equivocal.

Canyons have existed in the study area since at least $\mathrm{m} 3$ time. Together with sedimentary evidence of mass-flow deposits in Leg 150 cores, the canyons indicate that erosion and deposition were controlled by downslope processes even while the paleoshelf edge was far landward of the study area. Initiation of slope canyon cutting at $\mathrm{m} 3$ time ( $13.5 \mathrm{Ma}$, middle Miocene) is consistent with the significant middle Miocene increase in siliciclastic sediment supply documented by Poag and Sevon (1989) and Poag (1992). Mass-flow deposits, associated in particular with $\mathrm{m} 2$ and $\mathrm{ml}$, suggest that downslope sediment transport could also occur unconfined by the widely spaced canyons in this slope setting. Hemipelagic settling occurred between mass-flow events. Canyon-cutting and downslope sediment transport events were probably linked to glacioeustasy (Miller et al., this volume). Unconformities formed on the slope are, therefore, probably correlative with those formed beneath the shelf and which are inferred to be of eustatic origin (Greenlee et al., 1992; Miller and Mountain, 1994). However, undetermined leads or lags may exist between the timing of unconformities in these settings. Further work is required to document the precise spatial and temporal relationships between the alphanumeric slope reflections and the clinoform sequence boundaries that are well-defined beneath the shelf.

The large buried canyon, incised at approximately m 3 time (early middle Miocene) at Site 906, differs from modern, V-shaped slope canyons in its possession of a broad, planar floor. It is interpreted to have formed by slope failure. Later canyons incising horizons $\mathrm{ml}$ and $\mathrm{m} 0.5$ are $\mathrm{V}$ shaped and resemble those incising the modern slope. It is likely that both slope failure, probably coupled with headward erosion, and downslope erosion have contributed to canyon formation at different times and on different parts of the slope.

\section{ACKNOWLEDGMENTS}

R. Kemp of ODP together with Drs. J.M. Lorenzo and C.M. McHugh participated in the collection of seismic data during Leg 
150. We thank Drs. C.W. Poag, L.F. Pratson, and W.E. Galloway for their thoughtful and constructive reviews. This is University of Texas Institute for Geophysics contribution number 1224.

\section{REFERENCES}

Farre, J.A., McGregor, B.A., Ryan, W.B.F., and Robb, J.M., 1983. Breaching the shelfbreak: passage from youthful to mature phase in submarine canyon evolution. In Stanley, D.J., and Moore, G.T. (Eds.), The Shelfbreak: Critical Interface on Continental Margins. Spec. Publ.-Soc. Econ. Paleontol. Mineral., 33:25-39.

Greenlee, S.M., Devlin, W.J., Miller, K.G., Mountain, G.S., and Flemings, P.B., 1992. Integrated sequence stratigraphy of Neogene deposits, New Jersey continental shelf and slope: comparison with the Exxon model Geol. Soc. Am. Bull., 104:1403-1411.

Greenlee, S.M., and Moore, T.C., 1988. Recognition and interpretation of depositional sequences and calculation of sea-level changes from stratigraphic data - offshore New Jersey and Alabama Tertiary. In Wilgus, C.K., Hastings, B.S., Kendall, C.G.St. C., Posamentier, H.W., Ross, C.A., and Van Wagoner, J.C. (Eds.), Sea-level Changes: An Integrated Approach. Spec. Publ.-Soc. Econ. Paleontol. Mineral., 42:329-353.

Greenlee, S.M., Schroeder, F.W., and Vail, P.R., 1988. Seismic stratigraphic and geohistory analysis of Tertiary strata from the continental shelf off New Jersey: calculation of eustatic fluctuations from stratigraphic data. In Sheridan, R.E., and Grow, J.A. (Eds.), The Atlantic Continental Margin. Geol. Soc. Am., Geol. of North Am. Ser., 437-444.

Haq, B.U., Hardenbol, J., and Vail, P.R., 1987. Chronology of fluctuating sea levels since the Triassic. Science, 235:1156-1167.

Locker, S.D., and Laine, E.P., 1992. Paleogene-Neogene depositional history of the middle U.S. Atlantic continental rise: mixed turbidite and contourite depositional systems. Mar. Geol., 103:137-164.

Miller, K.G., Melillo, A.J., Mountain, G.S., Farre, J.A., and Poag, C.W. 1987. Middle to late Miocene canyon cutting on the New Jersey continental slope: biostratigraphic and seismic stratigraphic evidence. Geology, 15:509-512.

Miller, K.G., and Mountain, G.S., 1994. Global sea-level change and the New Jersey margin. In Mountain, G.S., Miller, K.G., Blum, P., et al., Proc, ODP, Init. Repts., 150: College Station, TX (Ocean Drilling Program), 11-20.

Miller, K.G., Wright, J.D., and Fairbanks, R.G., 1991. Unlocking the Ice House: Oligocene-Miocene oxygen isotopes, eustasy, and margin erosion. J. Geophys. Res., 96:6829-6848.

Mountain, G.S., 1987. Cenozoic margin construction and destruction offshore New Jersey. In Ross, C., and Haman, D. (Eds.), Timing and Depositional History of Eustatic Sequences: Constraints on Seismic Stratigraphy. Spec. Publ.-Cushman Found. Foraminiferal Res., 24:5783 .

Mountain, G.S., Lorenzo, J.M., and Fulthorpe, C.S., 1994. Underway geophysics. In Mountain, G.S., Miller, K.G., Blum, P., et al., Proc. ODP. Init. Repts., 150: College Station, TX (Ocean Drilling Program), 43-50.

Mountain, G.S., Miller, K.G., Blum, P., et al., 1994. Proc. ODP, Init. Repts., 150: College Station, TX (Ocean Drilling Program).

Mountain, G.S., and Tucholke, B.E., 1985. Mesozoic and Cenozoic geology of the U.S. Atlantic continental slope and rise. In Poag, C.W. (Ed.), Geo logic Evolution of the United States Atlantic Margin: New York (Van Nostrand Reinhold), 293-341.
Olsson, R.K., and Wise, S.W., 1987. Upper Maestrichtian to middle Eocene stratigraphy of the New Jersey slope and coastal plain. In van Hinte, J.E., Wise, S.W., Jr., et al., Init. Repts. DSDP, 93 (Pt. 2): Washington (U.S. Govt. Printing Office), 1343-1365.

Poag, C.W., 1985. Cenozoic and Upper Cretaceous sedimentary facies and depositional systems of the New Jersey slope and rise. In Poag, C.W. (Ed.), Geologic Evolution of the United States Atlantic Margin: New York (Van Nostrand Reinhold), 343-365.

, 1987. The New Jersey transect: stratigraphic framework and depositional history of a sediment-rich passive margin. In Poag, C.W. Watts, A.B., et al., Init. Repts. DSDP, 95: Washington (U.S. Govt. Printing Office), 763-817.

1992. U.S. middle Atlantic continental rise: provenance, dispersal, and deposition of Jurassic to Quaternary sediments. In Poag, C.W., and de Graciansky, P.C. (Eds.), Geologic Evolution of Atlantic Continental Rises: New York (Van Nostrand Reinhold), 100-156.

Poag, C.W., and Mountain, G.S., 1987. Late Cretaceous and Cenozoic evolution of the New Jersey continental slope and upper rise: an integration of borehole data with seismic reflection profiles. In Poag, C.W., Watts, A.B., et al., Init. Repts. DSDP, 95: Washington (U.S. Govt. Printing Office), 673-724.

Poag, C.W., and Sevon, W.D., 1989. A record of Appalachian denudation in postrift Mesozoic and Cenozoic sedimentary deposits of the U.S. middle Atlantic continental margin. Geomorphology, 2:119-157.

Poag, C.W., and Ward, L.W., 1993. Allostratigraphy of the U.S. Middle Atlantic Continental Margin-Characteristics, Distribution, and Depositional History of Principal Unconformity-bounded Upper Cretaceous and Cenozoic Sedimentary Units. Geol. Surv. Prof. Pap. U.S., 1542.

Poag, C.W., Watts, A.B., et al., 1987. Init. Repts. DSDP, 95: Washington (U.S. Govt. Printing Office).

Pratson, L.F., Ryan, W.B.F., Mountain, G.S., and Twichell, D.C., 1994. Submarine canyon initiation by downslope-eroding sediment flows: evidence in late Cenozoic strata on the New Jersey slope. Geol. Soc. Am. Bull., 106:395-412.

Reynolds, D.J., Steckler, M.S., and Coakley, B.J., 1991. The role of the sediment load in sequence stratigraphy: the influence of flexural isostasy and compaction. J. Geophys. Res., 96:6931-6949.

Robb, J.M., 1984. Spring sapping on the lower continental slope, offshore New Jersey. Geology, 12:278-282.

Steckler, M.S., Reynolds, D.J., Coakley, B.J., Swift, B.A., and Jarrard, R., 1993. Modelling passive margin sequence stratigraphy. In Posamentier, H.W., Summerhayes, C.P., Haq, B.U., and Allen, G.P. (Eds.), Sequence Stratigraphy and Facies Associations. Spec. Publ. Int. Assoc. Sedimentol., 18:19-41.

Twichell, D.C., and Roberts, D.G., 1982. Morphology, distribution, and development of submarine canyons on the United States Atlantic continental slope between Hudson and Baltimore canyons. Geology, 10:408412 .

van Hinte, J.E., Wise, S.W., Jr., et al., 1987. Init. Repts. DSDP, 93 (Pts. 1 and 2): Washington (U.S. Govt. Printing Office).

Wessel, P., and Smith, W.H.F., 1991. Free software helps map and display data. Eos, 72:441-446.

Date of initial receipt: 28 February 1995

Date of acceptance: 14 July 1995

Ms 150SR-021 